\title{
ADSORPTION OF CADMIUM ION FROM WATER USING ACTIVATED CARBON PRODUCED FROM PALM KERNEL SHELL
}

\author{
H. Ayedun \\ Department of Chemical Sciences, Olusegun Agagu University of Science and Technology, \\ P. M. B. 353, Okitipupa, Ondo State, Nigeria. \\ E-Mail: ht.ayedun@oaustech.edu.ng \\ Tel.: +234-8032952831
}

\begin{abstract}
Carbon produced from agricultural wastes could be a great adsorptive material in removal of metals from water. This study was conducted to remove Cadmium ion from water using activated carbon produced from palm kernel shell (PKS). Cd ion were adsorbed using various masses of PKS for a varied temperature, time and $\mathrm{pH}$. The concentration of $\mathrm{Cd}$ adsorbed were determined using Atomic Absorption Spectrophotometer (AAS). The results showed that the adsorption of $C d$ can be optimize within $2 \mathrm{hrs}$ when allowed to equilibrate with gentle agitation $(80 \mathrm{rpm})$ at $\mathrm{pH} 2$. The results obtained were further subjected to Langmuir, Freundlich and Temkin adsorption isotherms. It was found that the value for qm were 2000, 2.203 and 0.906 respectively indicating that the most suitable isotherm for Cd adsorption is Langmuir. This study indicates another way of utilizing PKS which is a common waste in rural area.
\end{abstract}

Key words: Adsorption, Cadmium, Kernel, Wastes

\section{INTRODUCTION}

The presence of metal ions is of special concern as they can accumulate in different components of the environment. It is well known that heavy metals can damage nerves, liver and bones and also interfere with the normal functioning of various metalloenzymes. Cadmium and its compounds are commonly used in battery manufacturing, electroplating, pigments, tanneries, metal finishing, fertilizers, and plastic manufacturing ${ }^{1,2}$. As a result, Cadmium is found in industrial effluents, which eventually accumulates in soil. The source of cadmium in soil is not limited to effluent discharges but majorly due to application of fertilizers. The human exposure route of cadmium is through food intake, inhalation of fine cadmium powder and ingestion of its soluble compounds. Cadmium is very toxic and carcinogenic even at low concentrations ${ }^{3}$. Activated carbon is a form of carbon that has been processed to make it extremely porous to have a very large surface area available for adsorption of metals ${ }^{4}$. The activated carbon has the strongest physical adsorption forces of the highest volume adsorbing porosity of any material known to mankind ${ }^{5}$. Some vegetable wastes (orange barks, olive cores and olive wastes) and seed (Abelmoschus esculentus) were used to remove cadmium and dyes respectively from aqueous solution by adsorption ${ }^{6,7}$. The adsorption process was affected by several parameters such as 
contact time, adsorbent mass, initial concentration of cadmium, and initial $\mathrm{pH}$ of the solution and particle size of the adsorbent. Granular red mud was used to remove cadmium ions from aqueous solutions. The experiments were conducted and equilibrium isotherms at different temperatures were determined and analyzed with a Freundlich model $^{8}$. Studies of the adsorption of Cd (II) by sawdust was investigated and the results were best fitted to the Langmuir isotherm ${ }^{9}$. Activated carbon produced from Ceiba pentandra hulls was used to remove copper and cadmium in aqueous solution and a good sorption potential were recorded ${ }^{10}$. Sugarcane bagasse, maize corncob and Jatropha oil cake was used for the removal of $\mathrm{Cd}$ (II) from aqueous solution ${ }^{11}$.

Adsorption isotherm can describe the interaction between adsorbent and adsorbate at equilibrium. Adsorption isotherms also express the surface properties and capacities of adsorbent. Isotherm models that are commonly used are Langmuir and Freundlich isotherms. The Temkin isotherm takes into account the effect of adsorbate -adsorbate interaction on adsorption. It proposes that the heat of adsorption of all the molecules in the layer would decrease linearly with the coverage due to these interactions ${ }^{12}$. The adsorption is characterized by a uniform distribution of binding energies. The linearized Temkin isotherm equation can be expressed as:

$\mathrm{q}_{\mathrm{e}}=\mathrm{B} \ln \mathrm{A}_{T}+\mathrm{Bln}_{\mathrm{e}}$

A graph of plot of $q_{e}$ versus $\ln C_{e}$ yield $B$ which is the constant related to the heat of adsorption and equilibrium binding constant, $A_{t}(1 / g)$. Cadmium is a heavy metal with high toxicity and very soluble in water. Cadmium accumulate in the human body and especially in the kidney. High exposure can lead to lungs cancer and prostate cancer. The objective of the present study is adsorbed $\mathrm{Cd}^{2+}$ ion from aqueous solution using carbon produced from palm kernel shell.

\section{MATERIALS AND METHODS}

\section{Materials}

The palm kernel shell used were collected Okitipupa area of Ondo state, Nigeria and it was sun dry for thirty days. It was activated by the addition of $0.5 \mathrm{M} \mathrm{H}_{2} \mathrm{SO}_{4}$ and carbonized in an oven to become activated carbon of palm kernel shell (APKS). All reagent used were of analytical grade supplied by Sigma Aldrich and were used without further purification. An atomic absorption spectrophotometer (Bulk scientific model) was used for the determination of metal concentration.

\section{Methods}

Stock solutions of $\mathrm{Cd}$ were prepared from its salt $\left(\mathrm{CdCl}_{2}\right.$ salt, $\left.0.124 \mathrm{~g} / \mathrm{L}\right)$. Other solutions 
were prepared by serial dilution of the stock to give $(10,50,100,200,500)$ ppm. Adsorption studies were carried out by equilibration in a water bath and agitated steadily.

Effect of concentration: Effect of concentration was determined by measuring $20 \mathrm{ml}$ of $(10,50,100,200,500) \mathrm{ppm}$ cadmium ion solutions into various conical flask after which varied masses $(0.1-1 \mathrm{~g})$ of adsorbent (APKS) was added. The mixtures were agitated for $2 \mathrm{hr}$ at $80 \mathrm{rpm}$ after which it was filtered and the filtrate were analyzed for Cd concentration.

Effect of mass of adsorbent: The effect of adsorbents masses was determined by adding varying amount of APKS $(0.1 \mathrm{~g}, 0.3$ $\mathrm{g}, 0.5 \mathrm{~g}, 1 \mathrm{~g}, 1.5 \mathrm{~g}$ and $2 \mathrm{~g}$ ) to $100 \mathrm{ppm}$ of $\mathrm{Cd}$ solution, allowed to attain equilibrium, agitated for $2 \mathrm{hrs}$, filtered and the filtrate was analyzed for Cd concentration.

Effect of $\mathrm{pH}$ : Effect of $\mathrm{pH}$ was determined by adjusting the $\mathrm{pH}$ with using $0.1 \mathrm{M} \mathrm{HNO}_{3}$ and $0.1 \mathrm{M} \mathrm{NaOH}$ respectively to read $\mathrm{pH}$ values $2,4,7,8$ and 10 .

Effect of temperature: Effect of temperature was determined by adjusting the temperature to $(25,30,35,40$ and 50$){ }^{\circ} \mathrm{C}$ while effect of agitation time was determined by varying the time $(1,2,3,4,5)$ hrs using $20 \mathrm{~mL}$ of 100 ppm of Cd ion solution.

Nigerian Journal of Chemical Research
The $\%$ adsorbed was calculated with the equation

$\mathrm{PA}=\left(\mathrm{Ci}-\mathrm{C}_{\mathrm{f}}\right) / \mathrm{Ci} \times 100$

Where $\mathrm{Ci}$ is the initial $\mathrm{Cd}$ concentration before adsorption, $\mathrm{C}_{\mathrm{f}}$ is the final $\mathrm{Cd}$ concentration after adsorption and PA is the \% adsorbed.

The sorption capacity was determined by

$\mathrm{Qe}=\mathrm{C}_{\mathrm{i}}-\mathrm{C}_{\mathrm{f}} / \mathrm{m}$ x V -----------2

Where Qe is sorption capacity $\left(\mathrm{mg} \mathrm{g}^{-1}\right)$; $\mathrm{V}$ is the volume of solution $(\mathrm{L}) ; \mathrm{m}$ is the mass of material $(\mathrm{g})$, and $\mathrm{C}_{\mathrm{i}}$ and $\mathrm{C}_{\mathrm{f}}$ are the initial and final (equilibrium) concentrations $\left(\mathrm{mg} \mathrm{L}^{-1}\right)$.

The sorption process between solid phase and solution was described by Langmuir ${ }^{13}$ :

Langmuir isotherm model is used for the sorption of molecules to the surface of solid sorbent. It assumes that the adsorption occurs in monolayer nature where the adsorption takes place at specific homogeneous sites within the adsorbent surface. There is no further adsorption can take place at that site once the dye molecule occupies the active site $^{14}$. The linearized equation of Langmuir isotherm is shown as below:

$$
\frac{\mathrm{C}_{\mathrm{e}}}{\mathrm{q}_{\mathrm{e}}}=\frac{1}{\mathrm{~K}_{\mathrm{L}} \mathrm{q}_{\mathrm{m}}}+\frac{1}{\mathrm{q}_{\mathrm{m}}} \mathrm{C}_{\mathrm{e}}
$$

where $\mathrm{q}_{\mathrm{e}}$ is sorption capacity $\left(\mathrm{mg}^{-1}\right)$; $\mathrm{q}_{\mathrm{m}}$ is maximum sorption capacity $\left(\mathrm{mg} \mathrm{g}^{-1}\right)$; $\mathrm{K}_{\mathrm{L}}$ is Langmuir adsorption constant related to the affinity of binding sites $\left(\mathrm{L} \mathrm{g}^{-1}\right)$; and $\mathrm{Ce}$ is 
equilibrium concentration $\left(\mathrm{mg} \quad \mathrm{L}^{-1}\right)$ and Freundlich equation ${ }^{13}$

A graph of plot of $\mathrm{C}_{\mathrm{e}} / \mathrm{q}_{\mathrm{e}}$ against $\mathrm{C}_{\mathrm{e}}$, gives the adsorption coefficient by the slope and intercept of the straight line. The graph plot should show a straight line with the slope of $1 / \mathrm{q}_{\mathrm{m}}$ and intercept of $1 / \mathrm{K}_{\mathrm{L}} \mathrm{q}_{\mathrm{m}}$. The essential characteristic of the Langmuir isotherm is that it could show a dimensionless constant which expressed by means of $\mathrm{R}_{\mathrm{L}}{ }^{15}$. The expression of $\mathrm{R}_{\mathrm{L}}$ is as follows:

$\mathrm{R}_{\mathrm{L}}=\frac{1}{1+\mathrm{K}_{\mathrm{L}} \mathrm{C}_{\mathrm{o}}}$

Where the nature of adsorption processes is unfavourable if $\mathrm{R}_{\mathrm{L}}$ higher than 1 . The adsorption is linear when $\mathrm{R}_{\mathrm{L}}$ equals to unity. The adsorption is favourable when $\mathrm{L}$ is in the range of 0 to 1 . The adsorption process is irreversible when $\mathrm{R}_{\mathrm{L}}$ is close to zero.

Linearized Freundlich isotherm can be express as:

$\ln \mathrm{q}_{\mathrm{e}}=\ln \mathrm{K}_{\mathrm{F}}+\frac{1}{\mathrm{n}_{\mathrm{F}}} \ln \mathrm{C}_{\mathrm{e}}$

where $\mathrm{Ce}$ is equilibrium concentration $\left(\mathrm{mg} \mathrm{L}^{-1}\right)$; qe is adsorption capacity (mg $\mathrm{g}^{-1)} ; \mathrm{K}_{\mathrm{F}}$ is the adsorption capacity of the adsorbent which represents the quantity adsorbed onto adsorbent for a unit equilibrium concentration. On the other hand, the constant $1 / \mathrm{n}_{\mathrm{F}}$ in range from 0 to 1 showed surface heterogeneity. It becomes more heterogeneous as it gets closer to zero ${ }^{16}$. A value for $1 / \mathrm{n}_{\mathrm{F}}$ above one is indicative of cooperative adsorption while $1 / \mathrm{n}_{\mathrm{F}}$ below one indicates a normal Langmuir isotherm ${ }^{17}$. The values for Freundlich constant $\mathrm{K}_{\mathrm{F}}$ and $1 / n_{F}$ were calculated from the slope of $1 n q_{e}$ versus $\operatorname{lnc}_{\mathrm{e} .}$.

\section{RESULTS AND DISCUSSION}

\section{Effect of initial concentration}

The higher the concentration of Cd solution, the more $\% \mathrm{Cd}$ ion adsorbed by APKS with the maximum value recorded for $1 \mathrm{~g}$ of the adsorbent (Figure 1). This may be due to availability of more active adsorption sites for $\mathrm{Cd}^{2+}$ at higher adsorbent concentration ${ }^{18,} 19$. The result from this study is consistent with the results previous study using coconut husk to remove $\mathrm{Cr}$ and $\mathrm{Ni}$ ions from simulated waste water ${ }^{20}$. Higher initial concentration occurred due to creation of required driving force to overcome liquid resistance $^{21}$.

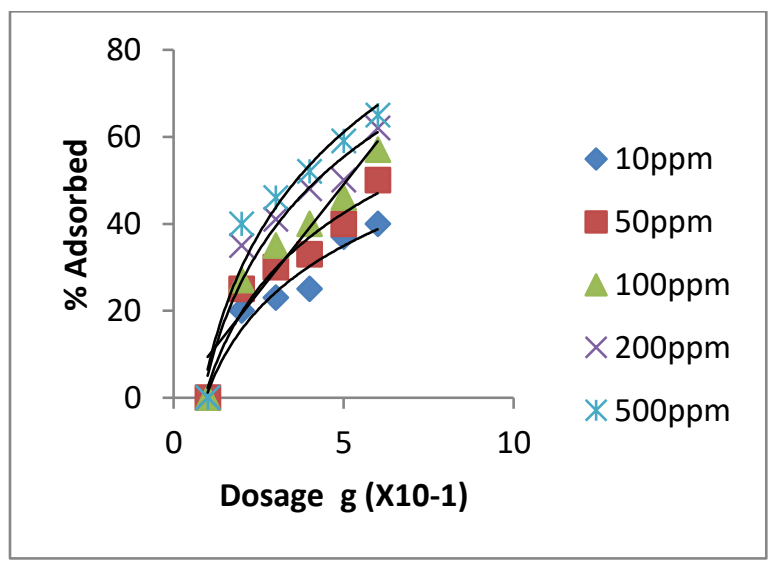

Figure 1: Effect of concentration of $\mathrm{Cd}^{2+}$ on $\%$ adsorbed 


\section{Effect of mass adsorbent}

The effect of mass of APKS dosage was studied by varying its amount from 0.1 to 2.5 $\mathrm{g} / \mathrm{l}$, while keeping other parameters $(\mathrm{pH}$, agitation speed, and contact time) constant. The percent $\mathrm{Cd}$ adsorbed were shown with the removal efficiency of the adsorbent increases with increasing dosage (Figure 2). Below $0.5 \mathrm{~g}$, there was no appreciable increase in $\%$ adsorbed due to nonavailability of enough site for adsorption. After $1.5 \mathrm{~g}$ of the adsorbent were added, there was no significant increase in adsorption. Using $100 \mathrm{ppm}$ solution of $\mathrm{Cd}$ ion, between $0.5 \mathrm{~g}$ and $1 \mathrm{~g}$ of APKS, a jump in $\%$ adsorbed from $20 \%$ to $60 \%$ was observed, however, between $1.5 \mathrm{~g}$ and $2 \mathrm{~g}$, a marginal increase from $65 \%$ to $67 \%$ was observed (Figure 3). This suggests that the higher the dosage of adsorbents in the solution, the more sites available for exchangeable ions up to the point of saturation. It also shows that after the saturation point, only part of the active sites are occupied by $\mathrm{Cd}^{2+}$, leading to a lower \% $\operatorname{adsorption}^{22}$.

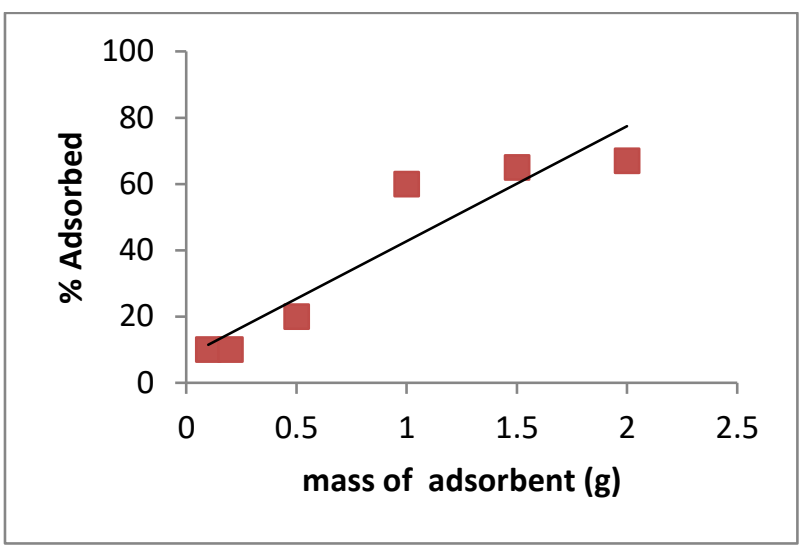

Figure 2: effect of mass of adsorbent on $\%$ adsorbed with concentration of 100ppm $\mathrm{Cd}^{2+}$.

\section{Effect of Contact Time}

The effect of contact time was investigated using different $\mathrm{Cd}$ ion concentration (10 ppm $500 \mathrm{ppm}$ ) and time ranging from 30 minutes to 7 hours. Other parameters such as dose of adsorbent, $\mathrm{pH}$ of solution, agitation speed and temperature were kept constant, while temperature was kept at $25^{\circ} \mathrm{C}$.It was observed that as the time increases the \% adsorbed increases for various concentrations (Figure $3)$. The binding capacity increases with time up to 4hours, after 4hours, there was no appreciable increase in \% adsorbed. 


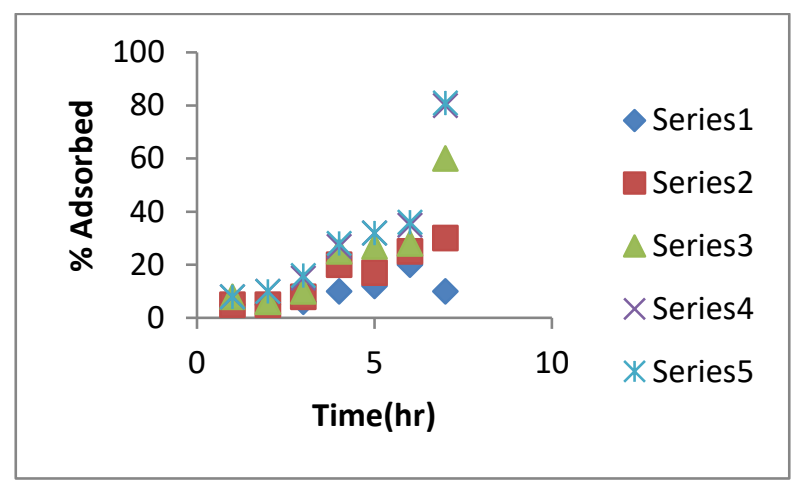

Key: series1-10ppm, series2-50ppm, series3100ppm, series 4-200ppm, series 5-500ppm

Figure 3: Effect of agitation time on $\%$ adsorbed

\section{Effect of solution $\mathrm{pH}$}

The $\mathrm{pH}$ affects the solubility of the metal ions and concentration of the counter ions on the functional groups of the adsorbent during adsorption reaction differently, therefore, it is very important to know the percent adsorbed at various $\mathrm{pH}$ values. The $\mathrm{pH}$ was varied between 2.0 to 9.0 and \% adsorbed was optimally recorded at $\mathrm{pH} 2$ (Figure 5). The uptake of free ionic $\mathrm{Cd}$ depends on $\mathrm{pH}$, as the $\mathrm{pH}$ increases the efficiency of the removal decreases. This is in consistence with results obtained by, who reported optimal metal removal efficiency in acidic $\mathrm{pH}(\mathrm{pH} 5)$. The $\mathrm{pH}$ of maximum adsorption is the $\mathrm{pH}$ at which acidic (or basic)

functional groups no longer contribute to the $\mathrm{pH}$ value of the solution ${ }^{23}$.

It can be deduced that activation of PKS with sulphuric acid yielded acidic surface.

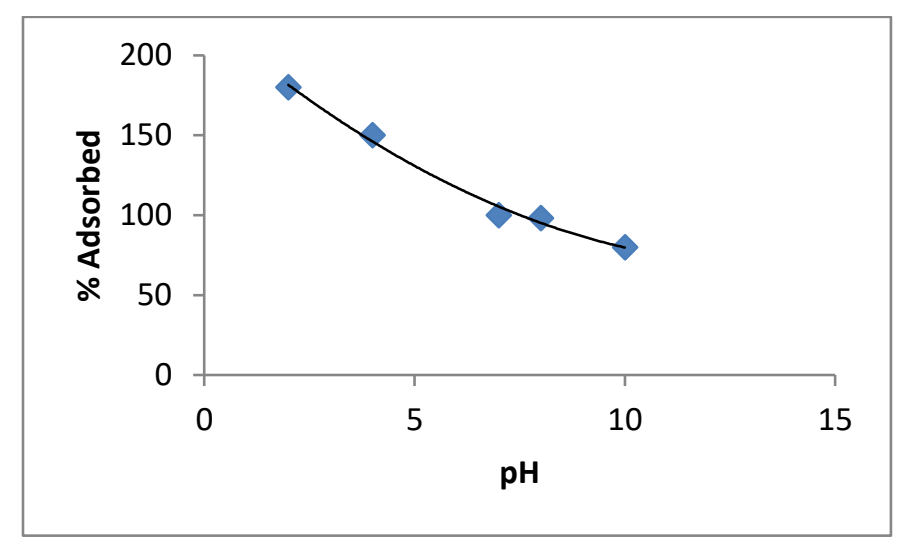

Figure 4: effect of $\mathrm{pH}$ variation on $\%$ adsorbed (using concentration of 100ppm $\mathrm{Cd}^{2+}$ )

The increase could be due to the fact that at low $\mathrm{pH}, \mathrm{Cd}$ exist as $\mathrm{Cd}^{2+}$ and can therefore be better adsorbed by the $\mathrm{C}=\mathrm{O}$ functional group on the adsorbent since oxygen is electronegative and can attract ions that are positively charged ${ }^{24}$. At low $\mathrm{pH}$, there is presence of a large number of $\mathrm{H}^{+}$ions, which in turn neutralizes the negatively charged adsorbent surface ${ }^{25}$.

\section{Effect of Temperature}

The effect of temperature was investigated at temperature of $298 \mathrm{~K}, 308 \mathrm{~K}, 318 \mathrm{~K}, 328 \mathrm{~K}$ and $338 \mathrm{~K}$ using concentration of $100 \mathrm{ppm}$ $\mathrm{Cd}^{2+}$ and $1 \mathrm{~g}$ of adsorbent APKS (Fig 5). Increase in temperature decreases \% adsorbed. The optimum temperature for the adsorption of $\mathrm{Cd}$ ion is $298 \mathrm{~K}$ above which there is no appreciable increase in \% adsorbed. This is similar to results obtained in adsorption of $\mathrm{Cu}$ using pods of Acacia nilotida ${ }^{26}$. 


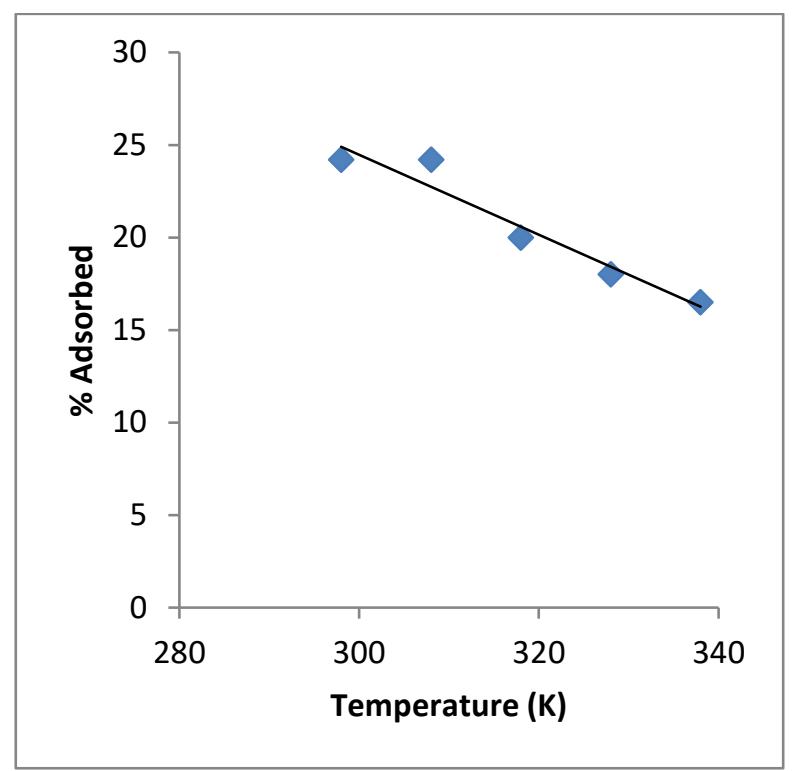

Figure 5: Effect of temperature variation on $\%$ adsorbed
The Langmuir, Freundlich and Temkin isotherm models (Figs 6, 7 and 8) were used to investigate the fitness of adsorption with the data shown in Table1. The Langmuir theory is based on the assumption that predicts monolayer coverage of the adsorbate on the outer surface of the adsorbent.

Table 1: Adsorption Isotherm constant for the present study

\section{Adsorption Isotherm}

\begin{tabular}{lll}
\hline Langmuir & Freundlich & Temkin \\
\hline $\mathrm{qe}=2 \times 10^{4}$ & $\mathrm{n}=0.665$ & $\mathrm{~B}=1.916$ \\
$\mathrm{R}^{2}=0.019$ & $\mathrm{R}^{2}=0.666$ & $\mathrm{R}^{2}=0.729$ \\
$\mathrm{~K}_{\mathrm{L}}=1.63 \times 10^{-3}$ & $\mathrm{~K}_{\mathrm{F}}=4.755$ & $\mathrm{~A}=1.572$ \\
$\mathrm{y}=5 \times 10^{-05} \mathrm{x}+0.326$ & $\mathrm{y}=1.504 \mathrm{x}-1.623$ & $\mathrm{y}=1.916 \mathrm{x}+3.620$ \\
$\mathrm{q}_{\mathrm{m}}=200$ & $\mathrm{q}_{\mathrm{m}}=2.203$ & $\mathrm{q}_{\mathrm{m}}=0.906$ \\
\hline
\end{tabular}

The Langmuir isotherm can be described by the dimensionless constant separation term $\mathrm{K}_{\mathrm{L}}$ to determine high affinity adsorption ${ }^{27}$. $\mathrm{K}_{\mathrm{L}}$ indicates the type of isotherm to be irreversible, if $\mathrm{K}_{\mathrm{L}}=0$, favorable, $\mathrm{K}_{\mathrm{L}}=$ between 0 and 1 , linear, $\mathrm{K}_{\mathrm{L}}>1$ unfavorable. The results shows that $\mathrm{K}_{\mathrm{L}}=$ $1.63 \times 10^{-3}$ which implies that it is very close to linear. The Freundlich isotherm which was based on multilayer adsorption on heterogeneous surface. The $1 / \mathrm{n}$ values indicates the type of isotherms. If $1 / n=0$, the adsorption

is irreversible, if $1 / \mathrm{n}$ is between 0 and $<1$, it is favorable, if $1 / \mathrm{n}$ is $>1$ it is unfavorable. From the present study the $1 / \mathrm{n}$ value is $>1(1 / \mathrm{n}=1.504)$ which indicate unfavorable adsorption reaction. The $\mathrm{R}^{2}$ value for Langmuir, Freundlich and Temkin are $0.019,0.666$ and 0.729 respectively. 
The maximum adsorption capacity was $\mathrm{q}_{\mathrm{m}}$ are 200, 2.203 and 0.906 respectively. The results showed that Langmuir adsorption is the best fit isotherm for the reaction between the $\mathrm{Cd}$ and activated palm kernel shell.

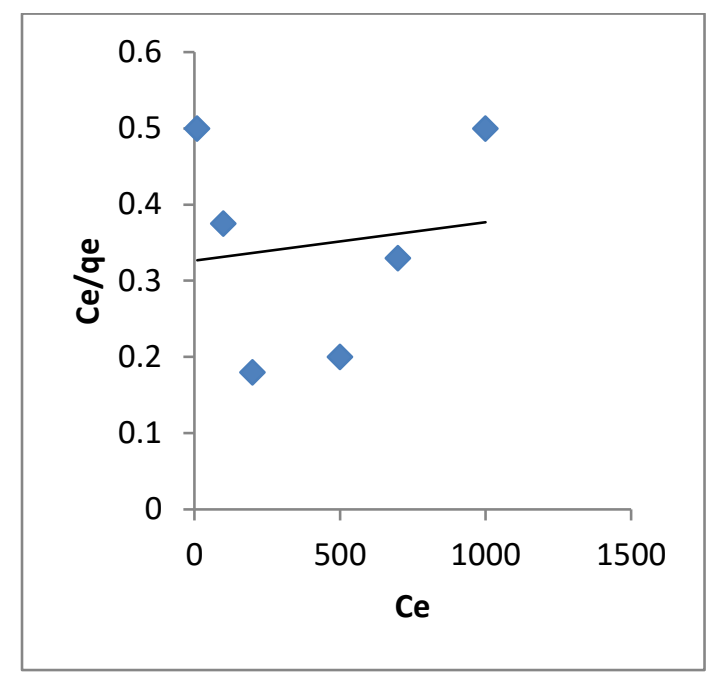

Figure 6: Langmuir isotherm plot for adsorption of Cd using carbonized palm kernel seed

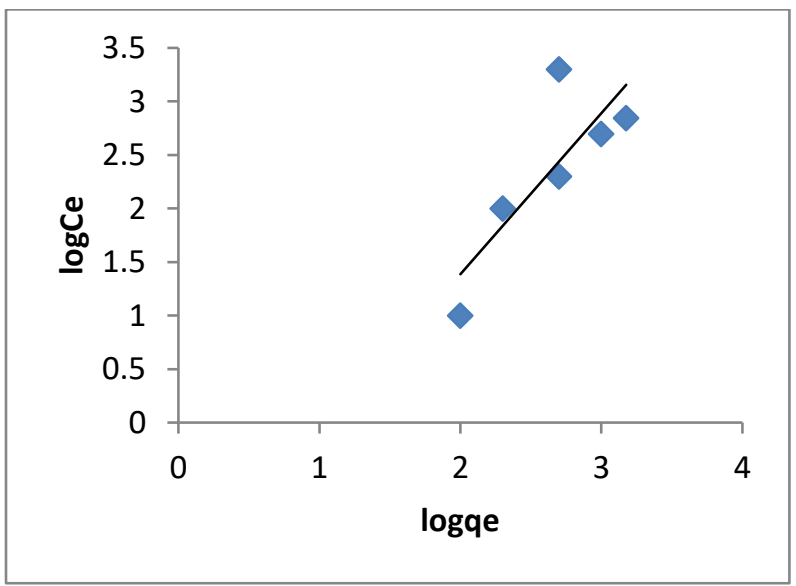

Figure 7: Freundlich Isotherm plot for adsorption of $\mathrm{Cd}$ using carbonized palm kernel shell.

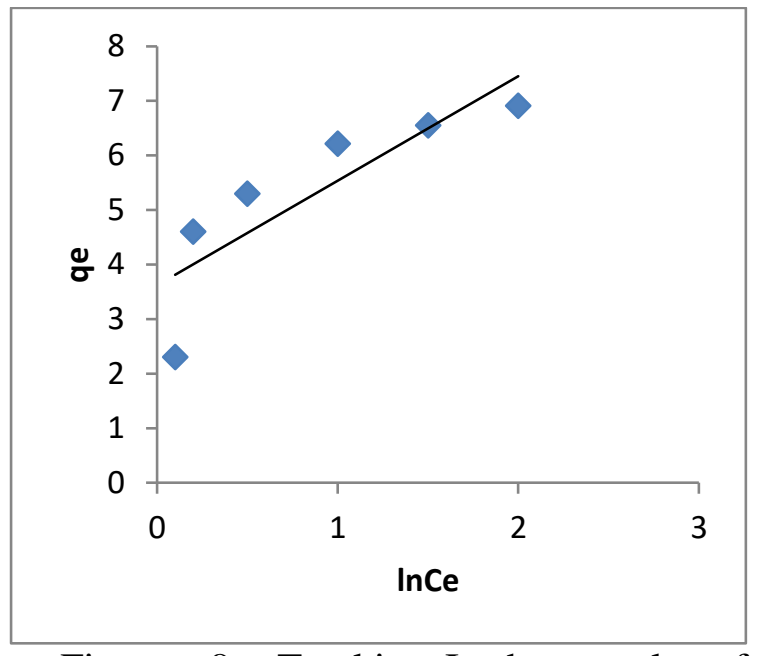

Figure 8: Temkin Isotherm plot for adsorption of $\mathrm{Cd}$ using carbonized palm kernel shell

\section{CONCLUSION}

Activated palm kernel shell can be used to remove $\mathrm{Cd}$ ion from aqueous solution. This can be achieved optimally at lower $\mathrm{pH}$, room temperature, high $\mathrm{Cd}$ concentration and moderate quantity of the adsorbent dosage. Large variation in parameters listed above will reduce the efficiency of the adsorbent.

\section{ACKNOWLEDGEMENT}

The assistance rendered by Mr. P. C. Nwachukwu and Mr. Isheyemi Olawale Bayo during the experiments is acknowledged.

\section{REFERENCES}

1. R. Sharma, A. Sarswat, C.U. Pittman \& D. Mohan (2017). Cadmium and lead remediation using magnetic and non-magnetic sustainable biosorbents derived from Bauhinia purpurea pods. RSC Advances. 7 (14): 8606-8624. doi: 10.1039/c6ra25295h. 
2. X. Zhang \& X. Wang (2015). Adsorption and desorption of nickel(II) ions from aqueous solution by a lignocellulose/ montmorillonite nanocomposite. Plos One. 10 (2): 1-21. doi: 10.1371/journal.pone.0117077.

3. Y.C. Sharma, V. Srivastava, V. Singh \& C.H. Weng (2009). Nano-adsorbents for the removal of metallic pollutants from water and wastewater. Environmental Technology. 30 (6): 583-609. doi: 10.1080/09593330902838080.

4. J.W. Hasler (1974). Purification with activated carbon: industrial, commercial and environmental, chemical publishing Inc. New York, N.Y. Pp35-42

5. J. Guo \& A.C. Lua (2002). Characterization of Adsorbent Prepared from Oil-palm Shell by $\mathrm{CO} 2$ Activation for Removal of Gaseous Pollutants. Mater. Lett. 55: 334 - 339.

6. N. Azouaou, Z. Sadaoui \& H. Mokaddem (2008). Removal of Cadmium from Aqueous Solution by Adsorption on Vegetable Wastes. Journal of Applied Sciences. 8: 4638 - 4643.

7. A.K. Nayak \& A. Pal (2017). Green and efficient biosorptive removal of methylene blue by Abelmoschus esculentus seed: process optimization and multi-variate modeling. Journal of Environmental Management. 200: 145-159. doi: 10.1016/j.jenvman.2017.05.045.

8. Z. Chunlei, L. Zhaokun, W. Yanqiu \& S. Xingdong (2007). Removal of Cadmium from Aqueous Solution by Adsorption on Granular Red Mud 9GRM. Separation and Purification Technology. 57(1):161-169 DOI: 10.1016/j.seppur.2007.03.013

9. A. Jumasiaha, T.G. Chuaha, J. Gimbonb, T.S.Y. Choonga \& I. Azni (2005). Adsorption of basic dye onto palm kernel shell activated carbon: sorption equilibrium and kinetics studies Desalination. 186: 57 64
10. R.M. Madhava, A. Ramesh, C.R.G. Purna $\&$ K. Seshaiah (2006). Removal of copper and cadmium from the aqueous solutions by activated carbon derived from Ceibapentandrahulls. Journal of Hazardous Materials. B129,123 - 129

11. M. P. Umesh, G.K.Kaur \& DhirajSud (2008). Removal of cadmium (II) from aqueous solutions by adsorption on agricultural waste biomass. Journal of Hazardous Materials. 154, 1149 - 1157.

12. M.J. Temkin \& V. Pyzhev (1940). Recent modifications to Langmuir isotherms. Acta Physiochimica URRS. 12: 217 - 222.

13. I. Langmuir (1916). The constitution and fundamental properties of solids and liquids. Journal of American Chemical Society. 38: 2221 - 2295.

14. H.M.F. Freundlich (1906). Over the adsorption in solution. Journal of Physical Chemistry 1906; 57: 385 - 470.

15.G. McKay (1996). Use of adsorbents for the removal of pollutants from wastewater. Boca Raton: CRC Press Inc. Pp179.

16. B.H. Hameed, J.M. Salman \& Ahmed (2009). Adsorption isotherm and kinetic modelling of 2, 4-D Pesticide on activated carbon derived from date stone. Journal of hazardous material. 163:121-126.

17. Haghseresht F, Lu G. Characteristic of phenolic compounds onto coal-reject derived adsorbents. Energy fuel 1998; 12: 1100-1107.

18. V. Fytianos, E. Voudrias \& E. Kokkalis (2000). Sorption - desorption behavior of 2,4-dichlorophenol by marine sediments. Chemosphere. 40: 3 - 6 . 
19. S. Babel \& T.A. Kurniawan (2004). Cr (VI) removal from synthetic wastewater using coconut shell charcoal and commercial activated carbon modified with oxidizing agents and/or chitosan. Chemosphere. 54: 951 967.

20. C. Song, S. Wu, M. Cheng, P. Tao, M. Shao $\&$ Gao (2014). Adsorption Studies of Coconut Shell Carbons Prepared by $\mathrm{KOH}$ Activation for Removal of Lead(II) From Aqueous Solutions. Sustainability. 6: 86 - 98 .

21. O.K. Olayinka, O.A. Oyedeji \& O.A Oyeyiola (2009). Removal of chromium and nickel ions from aqueous solution by adsorption on modified coconut husk. African Journal of Environmental Science and Technology. 3: 286-293.

22. A. Pfeifer \& M. Scerget (2020). A review: Comparison of different adsorbent for removal of $\mathrm{Cr}$

(VI), Cd (II) and Ni (II). Turkish Journal of Chemistry. 44: $859-883$

23. Y. Li, Q. Du, X. Wang, P. Zhang, D. Wang, Z. Wang \& Y. Xia (2010). Removal of lead from aqueous solution by activated carbon prepared from Enteromorpha prolifera by zinc chloride activation. J. Hazard. Mater. 183: 583 - 589.

24. S. M. Nomanbhay \& K. Palanisamy (2005). Removal of heavy metal from industrial wastewater using chitosan coated oil palm shell charcoal. Electronic Journal of Biotechnology. 8: $44-53$.

25. I. Dambies, C. Guimon, S. Yiacoumi \& E. Guibal (2001). Characterization of metal ion interactions with chitosan by X-ray photoelectron spectroscopy. Colloids and Surfaces. 177: 203 - 214.

26.D.C. Sharma \& C.F. Foster (1994). The treatment of chromium wastewaters using the sorptive potential of leaf mould. Biores. Technol. 49: 31 - 40.

27. K. Gupta \& A. Patra (2017). Dhole K. Optically Controlled Electron Transfer Reaction Kinetics and Solvation Dynamics: Effect of Franck-Condon States September 2017. Journal of Physical Chemistry Letters. 8(18) DOI: $\underline{10.1021 / \text { acs.jpclett.7b01938 }}$

26. B.A. Dar, A. Taher, A. Wani \& M. Farooqu (2013). Isotherms and thermodynamic studies on adsorption of copper on powder of shed pods of Acacia nilotica. Journal of Environmental Chemistry and Ecotoxicology. 5: 17 - 20.

27. F. Ahmad, W. Mohd, A.W. Daud, M.A. Ahmad \& R. Radzi (2012). Cocoa (Theobroma cacao) shell-based activated carbon by $\mathrm{CO}_{2}$ activation in removing of cationic dye from aqueous solution, Kinet. Equilib. Stud. Chem. Eng. Res. Des. 90, 1480 - 1490. 